\title{
PLACE AND MODALITIES OF LAPAROSCOPY IN SURGICAL MANAGEMENT OF SUSPECTED ADNEXAL MASSES
}

\author{
Charles Chapron ${ }^{1}$, Jean-Bernard Dubuisson, Sylvie Capella-Allouc \& Xavier Fritel
}

Service de chirurgie Gynécologique, Clinique Universitaire Baudelocque, C.H.U. Cochin Port-Royal, 123, Boulevard Port-Royal, 75014, Paris, France

\section{TABLE OF CONTENTS}

\author{
1. Abstract \\ 2. Introduction \\ 3. Operative Procedure \\ 4. Results \\ 5. Discussion \\ 6. References
}

\section{ABSTRACT}

Only benign adnexal masses are suitable for treatment by operative laparoscopy. Ovarian cancer must always be managed by midline laparotomy. In our experience the preoperative workup (clinical examination, study of past history, trans vaginal ultrasonography, doppler, tumoral markers etc.) together with the diagnostic phase of laparoscopy provide a sensitivity value of $100 \%$, a positive predictive value of $50 \%$ and a negative predictive value of $100 \%$ for diagnosis of malignancy. Provided a strict selection, laparoscopy is reliable both for the diagnosis and the management of benign ovarian masses.

\section{INTRODUCTION}

The progress made during the past few years in gynecologic laparoscopic surgery has been considerable. Distinct advantages of operative surgery over laparotomy are now well known. Several series (1-4) have demonstrated that it is now perfectly possible to laparoscopically treat patients presented with ovarian cysts. The laparoscopic management can be either conservative (intra or trans-parietal cystectomy) or radical (adnexectomy or ovariectomy). Surgical treatment of ovarian cancer must be carried out in all cases via midline laparotomy and operative laparoscopy can only be considered when the cyst to be treated is benign. The problem, therefore, is to define the place and modalities for laparoscopy in the diagnosis and management of the adnexal masses. In cases of suspected adnexal masses, the treatment must be radical. Semm (5) was the first to report

Received: 9/16/96; Accepted: 9/26/96.

${ }^{1}$ To whom correspondence should be addressed at Service de chirurgie Gynécologique, Clinique Universitaire Baudelocque, C.H.U. Cochin PortRoyal, 123, Boulevard Port-Royal, 75014 Paris, France, Tel: 19-33-1-42-34-11-50, Fax: 19-33-1-4051-77-62. laparoscopic adnexectomy in 1980. Since then, several authors (6-11) using various methods have reported their experience with this procedure. The aim of this study is to characterize the indications and specify the modalities of adnexectomy for patients presenting with an adnexal mass.

\section{OPERATIVE PROCEDURE}

We consider that the existence of an adnexal mass is a contraindication to surgery via the vaginal route (12). So when an adnexectomy is indicated for patients with an adnexal mass, we carried out the operative procedure either by laparoscopy or by laparotomy. For patients presenting with an adnexal mass, the preoperative assessment was of prime importance to rule out and/or to diagnose malignancy. The elements of the preoperative assessment were the following: clinical examination, ultrasonography, doppler and assays for tumor markers. In the presence of extra-ovarian signs of malignancy during the preoperative workup the patient underwent laparotomy and no initial laparoscopy. When a laparoscopy was carried out, the first phase was purely diagnostic. If any extra-ovarian signs existed which raised the suspicion of malignancy during this diagnostic laparoscopy phase, we resorted to laparotomy. In other situations, it was possible to perform a laparoscopic adnexectomy. When we carried out adnexectomy via laparoscopy, the different steps included the following: diagnostic investigation of the adnexa and then the whole abdomino-pelvic cavity with systematic peritoneal cytology sampling; identification of the ureters; and if necessary, preliminary adhesiolysis; the adnexectomy itself, with hemostasis using bipolar coagulation in every case; extraction of the excised tissues which in certain situations (ovarian cysts in the peri- or postmenopausal period, dermoid cysts, endometriotic cysts, etc.) required the use of an endoscopic bag (13); and checking on hemostasis and thorough abdomino-pelvic cleaning. 
Table 1. Surgical modalities for adnexectomy carried out for adnexal mass ${ }^{1}$

\begin{tabular}{|c|c|c|c|c|c|c|}
\hline \multirow{2}{*}{$\begin{array}{l}\text { Operative } \\
\text { Procedure }\end{array}$} & \multicolumn{2}{|c|}{ 1989-1991 } & \multicolumn{2}{|c|}{ 1992-1994 } & \multicolumn{2}{|c|}{ Total } \\
\hline & $\mathrm{n}^{2}$ & $\%$ & $\mathbf{n}^{2}$ & $\%$ & $\mathbf{n}^{2}$ & $\%$ \\
\hline Laparotomy & 29 & 50.0 & 36 & 28.1 & 65 & 34.9 \\
\hline - From the outset & 22 & 37.9 & 24 & 18.7 & 46 & 24.7 \\
\hline - Conversion & 7 & 12.1 & 12 & 9.4 & 19 & 10.2 \\
\hline Operative Laparoscopy & 29 & 50.0 & 92 & 71.9 & 121 & 65.6 \\
\hline
\end{tabular}

1: From Ref. 14: Chapron et al. Eur. J. Obstet. Gynecol. Reprod. Biol. (In press).

${ }^{2}: \mathrm{n}=$ number of patients.

Table 2. Surgical modalities for adnexectomy carried out for adnexal mass: Indications for laparotomy from the outset $^{1}$

\begin{tabular}{|c|c|c|c|c|c|c|}
\hline \multirow[t]{2}{*}{ INDICATIONS } & \multicolumn{2}{|c|}{ 1989-1991 } & \multicolumn{2}{|c|}{ 1992-1994 } & \multicolumn{2}{|c|}{ Total } \\
\hline & $\mathrm{n}^{2}$ & $\%$ & $n^{2}$ & $\%$ & $n^{2}$ & $\%$ \\
\hline Ovarian cancer: & 5 & 22.7 & 14 & 58.2 & 19 & 41.4 \\
\hline - Certain from pre operative workup: & 2 & 9.1 & 2 & 8.2 & 4 & 8.8 \\
\hline - Very strong suspicious of malignancy: & 3 & 13.6 & 12 & 50.0 & 15 & 32.6 \\
\hline Size of the mass & 4 & 18.3 & 1 & 4.2 & 5 & 10.9 \\
\hline Associated hysterectomy & 8 & 36.4 & 3 & 12.5 & 11 & 23.7 \\
\hline Hemoperitoneum & 1 & 4.5 & 0 & 0.0 & 1 & 2.2 \\
\hline $\begin{array}{l}\text { Severe infection } \\
\text { (pelvic abscess) }\end{array}$ & 1 & 4.5 & 0 & 0.0 & 1 & 2.2 \\
\hline Serious past history of surgery & 1 & 4.5 & 5 & 20.9 & 6 & 13.0 \\
\hline $\begin{array}{l}\text { Medical counter indication } \\
\text { for laparoscopy }\end{array}$ & 2 & 9.1 & 1 & 4.2 & 3 & 6.6 \\
\hline TOTAL & 22 & 100.0 & 24 & 100.0 & 46 & 100.0 \\
\hline
\end{tabular}

: From Ref. 14: Chapron et al. Eur. J. Obstet. Gynecol. Reprod. Biol. (In press).

${ }^{2}: \mathrm{n}=$ number of patients.

\section{RESULTS}

From January 1, 1989 to December 31, 1994, we performed adnexectomy for an adnexal mass in 186 cases (14). The modalities of the surgical treatment are presented in Table 1.

It was possible to perform the treatment by operative laparoscopy in $65.1 \%$ of the cases (121 cases). Sixty five patients $(34.9 \%)$ were treated by laparotomy. For 46 patients $(24.7 \%)$, the laparotomy was decided from the outset and in 19 cases $(10.2 \%)$ it was changed to laparotomy. The rate of laparoscopic treatment increased with the surgeon's experience (Table 1).
The indications for laparotomy from the outset $(n=46)$ are presented in Table 2.

The decision for laparotomy from the outset was motivated by a suspicion of ovarian malignancy in $41.3 \%$ of cases (19 patients) (Table 2). For the 27 other patients $(58.7 \%)$, the indications for laparotomy were the following: emergency operation in a context of considerable hemoperitoneum (2 liters) in a patient with adnexal torsion (1 case) (15); voluminous but not suspicious ovarian masses (5 patients): in three cases, these were dermoid cysts, measuring 9, 10 and $15 \mathrm{~cm}$ while two cases were ovarian fibrothecomas 
Table 3. Surgical modalities for adnexectomy carried out for adnexal mass: Indications for conversion to laparotomy ${ }^{1}$

\begin{tabular}{|c|c|c|c|c|c|c|}
\hline \multirow[t]{2}{*}{ Indications } & \multicolumn{2}{|c|}{ 1989-1991 } & \multicolumn{2}{|c|}{ 1992-1994 } & \multicolumn{2}{|c|}{ Total } \\
\hline & $\mathrm{n}^{2}$ & $\%$ & $n^{2}$ & $\%$ & $\mathrm{n}^{2}$ & $\%$ \\
\hline Severe adhesions & 1 & 14.3 & 6 & 50.0 & 7 & 36.8 \\
\hline Associated procedure & 0 & 0.0 & 1 & 8.3 & 1 & 5.3 \\
\hline Suspicion of maligancy $^{3}$ & 6 & 85.7 & 5 & 41.7 & 11 & 57.9 \\
\hline Total & 7 & 100.0 & 12 & 100.0 & 19 & 100.0 \\
\hline
\end{tabular}

${ }^{1}$ : From Ref. 14: Chapron et al. Eur. J. Obstet. Gynecol. Reprod. Biol. (In press).

2: $\mathrm{n}=$ number of patients.

${ }^{3}$ : during diagnostic phase of laparoscopy when pre operative workup was reassuring

Table 4. Surgical modalities for adnexectomy carried out for adnexal mass: Histological results ${ }^{1}$

\begin{tabular}{|c|c|c|c|c|c|c|}
\hline \multirow[t]{2}{*}{ Final Histology } & \multicolumn{2}{|c|}{$\begin{array}{l}\text { Laparotomy } \\
\qquad \mathbf{N}=65\end{array}$} & \multicolumn{2}{|c|}{$\begin{array}{l}\text { Laparoscopy } \\
\qquad \mathbf{N}=121\end{array}$} & \multicolumn{2}{|c|}{$\begin{array}{l}\text { TOTAL } \\
N=186\end{array}$} \\
\hline & $n^{2}$ & $\%$ & $n^{2}$ & $\%$ & $n^{2}$ & $\%$ \\
\hline \multicolumn{7}{|l|}{$\begin{array}{l}\text { 1) Benign lesions: } \\
\text { a) Benign }\end{array}$} \\
\hline Ovarian cyst $(\mathrm{OC})$ : & 43 & 66.1 & 107 & 88.4 & 150 & 80.6 \\
\hline - serous: & 15 & 23.0 & 42 & 34.7 & 57 & 27.9 \\
\hline - dermoid: & 7 & 10.8 & 11 & 9.1 & 18 & 9.7 \\
\hline - endometrioma: & 6 & 9.2 & 30 & 14.1 & 36 & 19.4 \\
\hline - mucinous: & 6 & 9.2 & 7 & 5.8 & 13 & 7.0 \\
\hline - fonctional: & 3 & 4.6 & 11 & 9.1 & 14 & 7.5 \\
\hline - context of torsion: & 2 & 3.1 & 1 & 0.8 & 3 & 1.6 \\
\hline - not specified: & 4 & 6.1 & 5 & 4.1 & 9 & 4.8 \\
\hline \multicolumn{7}{|l|}{ b) Adnexal masses } \\
\hline with no OC: & 7 & 10.8 & 14 & 11.6 & 21 & 11.3 \\
\hline - Hydrosalpinx: & 3 & 4.6 & 3 & 2.5 & 6 & 3.2 \\
\hline - false peritoneal cyst: & 1 & 1.5 & 2 & 1.7 & 3 & 1.6 \\
\hline - Tubo-ovarian abscess: & 1 & 1.5 & 0 & 0.0 & 1 & 0.5 \\
\hline - Fibrothecoma: & 2 & 3.1 & 4 & 3.3 & 6 & 3.2 \\
\hline - Para-tubal cyst: & 0 & 0.0 & 5 & 4.1 & 5 & 2.7 \\
\hline Sub total & 50 & 76.9 & 121 & 100.0 & 171 & 91.9 \\
\hline \multicolumn{7}{|l|}{ 2) Malignant lesions: } \\
\hline Malignant OC: & 15 & 23.1 & 0 & 0.0 & 15 & 8.1 \\
\hline TOTAL & 65 & 100.0 & 121 & 100.0 & 186 & 100.0 \\
\hline
\end{tabular}

${ }_{1}^{1}$ : From Ref. 14: Chapron et al. Eur. J. Obstet. Gynecol. Reprod. Biol. (In press).

${ }^{2}: \mathrm{n}=$ number of patients.

each measuring $10 \mathrm{~cm}$; severe infectious abdominopelvic syndrome (pelvic abscess) (1 patient); past history of considerable surgery and severe adhesions (6patients); medical contraindication for laparoscopy (3 patients); and the need to associate hysterectomy with the adnexectomy (11 patients).

The indications for conversion to laparotomy $(n=19)$ are presented in Table 3 . For 11 patients $(57.9 \%)$, the laparotomy was performed since malignancy was suspected during the diagnostic phase of laparoscopy. In 8 cases $(72.7 \%)$, the final pathology results confirmed that there was indeed a malignant tumor ( 6 borderline tumors and 2 cancers). In $42.1 \%$ of cases ( 8 patients), the laparotomy was done for the following reasons: the necessity of carrying out myomectomy under anesthesia for an interstitial myoma measuring $8 \mathrm{~cm}$ (1 patient); the 
Table 5. Reliability of laparoscopy for the diagnosis of malignancy in adnexal masses ${ }^{1}$

\begin{tabular}{|c|c|c|c|c|c|}
\hline \multirow{3}{*}{$\begin{array}{l}\text { Suspected } \\
\text { Diagnosis }\end{array}$} & \multirow[b]{3}{*}{$\mathbf{N}^{2}$} & \multicolumn{4}{|c|}{ Final Histology } \\
\hline & & \multicolumn{2}{|c|}{ Benign } & \multicolumn{2}{|c|}{ Malignant } \\
\hline & & $n^{2}$ & $\%$ & $\mathbf{n}^{2}$ & $\%$ \\
\hline Malignant & 30 & 15 & 50.0 & 15 & 50.0 \\
\hline Benign & 156 & 156 & 100.0 & 0 & 0.0 \\
\hline
\end{tabular}

1: From Ref. 14: Chapron et al. Eur. J. Obstet. Gynecol. Reprod. Biol. (In press).

${ }^{2}: \mathrm{n}=$ number of patients.

finding of severe tight adhesions between the adnexae and bowel ( 7 cases; $36.8 \%$ ).

The pathological findings are presented in Table 4. We performed a frozen section examination in 13 cases. For all these cases $(100 \%)$, the final histology confirmed the results of frozen section examination. The reliability of laproscopy for the diagnosis of malignancy in adnexal masses is presented in Table 5.

For the 30 patients $(16.1 \%)$ suspected of having malignant lesions, only half the patients $(50 \%$;

15 cases) did in fact had a neoplastic ovarian lesion. All the neoplastic lesions $(100 \%)$ were detected as suspicious either during the preoperative workup or during the diagnostic phase of laparoscopy. All patients with a malignant lesion were operated by laparotomy (Table 6).

For patients presenting with benign adnexal masses, it was possible to perform a laparoscopic treatment in $70.8 \%$ of cases (121 patients) (Table 7).

These results demonstrate that for the diagnosis of malignancy, the preoperative workup and the diagnostic phase of laparoscopy have a sensitivity of $100 \%$, a positive predictive value of $50 \%$ and a negative predictive value of $100 \%$.

\section{DISCUSSION}

The results reported here confirm that it is possible to carry out adnexectomy via laparoscopy in patients with an adnexal mass (1-11).

The preoperative assessment for the diagnosis of malignancy in adnexal masses can not be established in $100 \%$ (16). Whether used separately or in combination, clinical examination, ultrasonography, doppler, and assaying for tumor markers do not allow the diagnosis of malignancy to be firmly established in an adnexal mass (Table 8). Anatomopathological study is required to reveal the benign versus malignant nature of an adnexal mass. In a previously published, manuscript we demonstrated that laparoscopy is as reliable as laparotomy for establishing the diagnosis of malignancy for an ovarian tumor (16).

Our results of laparoscopic management of patients presenting with an adnexal mass are comparable to the previously published series (2-4) (Table 9).

If the malignant nature of a lesion limited to the ovary is missed during the diagnostic phase of laparoscopy, there is a risk of dissemination with the problems of peritoneal dissemination and abdominal wall metastasis. To prevent these risks, we recommend adnexectomy without opening the cyst and to place the adnexae intact inside an endoscopic bag before extraction (13).

Provided that patients are selected very strictly, it is possible to carry out adnexectomy using laparoscopic surgery in patients with an adnexal mass. We propose in Figure 1, a therapeutic outline

Table 6: Surgical modalities for adnexectomy carried out for patients presenting a malignant pathology ${ }^{1}$.

\begin{tabular}{|c|c|c|c|c|c|c|}
\hline \multirow{2}{*}{$\begin{array}{l}\text { Operative } \\
\text { procedure }\end{array}$} & \multicolumn{2}{|c|}{ 1989-1991 } & \multicolumn{2}{|c|}{ 1992-1994 } & \multicolumn{2}{|c|}{ Total } \\
\hline & $n^{2}$ & $\%$ & $\mathbf{n}^{2}$ & $\%$ & $n^{2}$ & $\%$ \\
\hline Laparotomy & 7 & 100.0 & 8 & 100.0 & 15 & 100.0 \\
\hline - From the outset & 2 & 28.6 & 5 & 62.5 & 7 & 46.7 \\
\hline - Conversion & 5 & 71.4 & 3 & 37.5 & 8 & 53.3 \\
\hline Operative Laparoscopy & 0 & 0.0 & 0 & 0.0 & 0 & 0.0 \\
\hline TOTAL & 7 & 100.0 & 8 & 100.0 & 15 & 100.0 \\
\hline
\end{tabular}

${ }^{1}$ : From Ref. 14: Chapron et al. Eur. J. Obstet. Gynecol. Reprod. Biol. (In press).

${ }^{2}: \mathrm{n}=$ number of patients. 
Laparoscopy for adnexal masses

Table 7. Surgical modalities for adnexectomy carried out for patients presenting a benign pathology ${ }^{1}$.

\begin{tabular}{|c|c|c|c|c|c|c|}
\hline \multirow{2}{*}{$\begin{array}{l}\text { Operative } \\
\text { procedure }\end{array}$} & \multicolumn{2}{|c|}{ 1989-1991 } & \multicolumn{2}{|c|}{ 1992-1994 } & \multicolumn{2}{|c|}{ Total } \\
\hline & $n^{2}$ & $\%$ & $n^{2}$ & $\%$ & $n^{2}$ & $\%$ \\
\hline Laparotomy & 22 & 43.1 & 28 & 23.3 & 50 & 29.2 \\
\hline - From the outset & 20 & 39.2 & 19 & 15.8 & 39 & 22.8 \\
\hline - Conversion & 2 & 3.9 & 9 & 7.5 & 11 & 6.4 \\
\hline Operative laparoscopy & 29 & 56.9 & 92 & 76.7 & 121 & 70.8 \\
\hline TOTAL & 51 & 100.0 & 120 & 100.0 & 171 & 100.0 \\
\hline
\end{tabular}

${ }^{1}$ : From Ref. 14: Chapron et al. Eur. J. Obstet. Gynecol. Reprod. Biol. (In press).

${ }^{2}: \mathrm{n}=$ number of patients.

Table 8. Value of pre-operative assessment for the diagnosis of malignancy in adnexal mass ${ }^{1}$

\begin{tabular}{|c|c|c|}
\hline $\begin{array}{l}\text { Preoperative } \\
\text { assessment }\end{array}$ & Specificity & Sensitivity \\
\hline $\begin{array}{l}\text { - Abdominal } \\
\text { ultrasonography }\end{array}$ & $78 \%$ & $74 \%$ \\
\hline $\begin{array}{l}\text { - Vaginal } \\
\text { ultrasonography }\end{array}$ & $79 \%$ & $83 \%$ \\
\hline - Doppler & $89 \%$ & $92 \%$ \\
\hline - CA-125 & $70 \%$ & $80 \%$ \\
\hline - Associations & $62-99 \%$ & $78-100 \%$ \\
\hline
\end{tabular}

for the management of these patients. The different conditions for this therapeutic approach include the following. For adnexal masses which are obviously malignant and/or when there are signs of extraovarian dissemination, the treatment must be midline laparotomy from the outset. Laparoscopy can be carried out in all other cases. The first phase in this laparoscopy is devoted to the diagnosis and the search for any signs which indicate presence of a possible malignancy. The existence of any extra-ovarian suspicious signs of malignancy require immediate laparotomy under anesthesia. Whenever there is any doubt as to the existence of a malignant lesion strictly confined to the ovary, diagnostic ovariectomy via laparoscopy is feasible. This approach is only valid provided that the adnexectomy is carried out without opening the cyst, and that the excised tissues are extracted using an endoscopic bag, and that frozen examination is possible (16).

Table 9. Reliability of laparoscopy for the diagnosis of malignancy in ovarian masses

\begin{tabular}{|c|c|c|c|c|}
\hline & \multicolumn{4}{|c|}{ References Cited From } \\
\hline & Ref 2 & Ref 4 & Ref 3 & Ref 14 \\
\hline Number & 757 & 1011 & 550 & 186 \\
\hline Malignant tumors & 19 & 4 & 11 & 15 \\
\hline - Diagnosed & 19 & 2 & 11 & 15 \\
\hline - Unrecognized & 0 & 2 & 0 & 0 \\
\hline Falsely suspicious masses & 27 & 4 & 14 & 30 \\
\hline Sensitivity & $100 \%$ & $50 \%$ & $100 \%$ & $100 \%$ \\
\hline Specificity & $97 \%$ & $99 \%$ & $98 \%$ & $91 \%$ \\
\hline Predictive value for malignancy & $41 \%$ & $33 \%$ & $44 \%$ & $50 \%$ \\
\hline
\end{tabular}




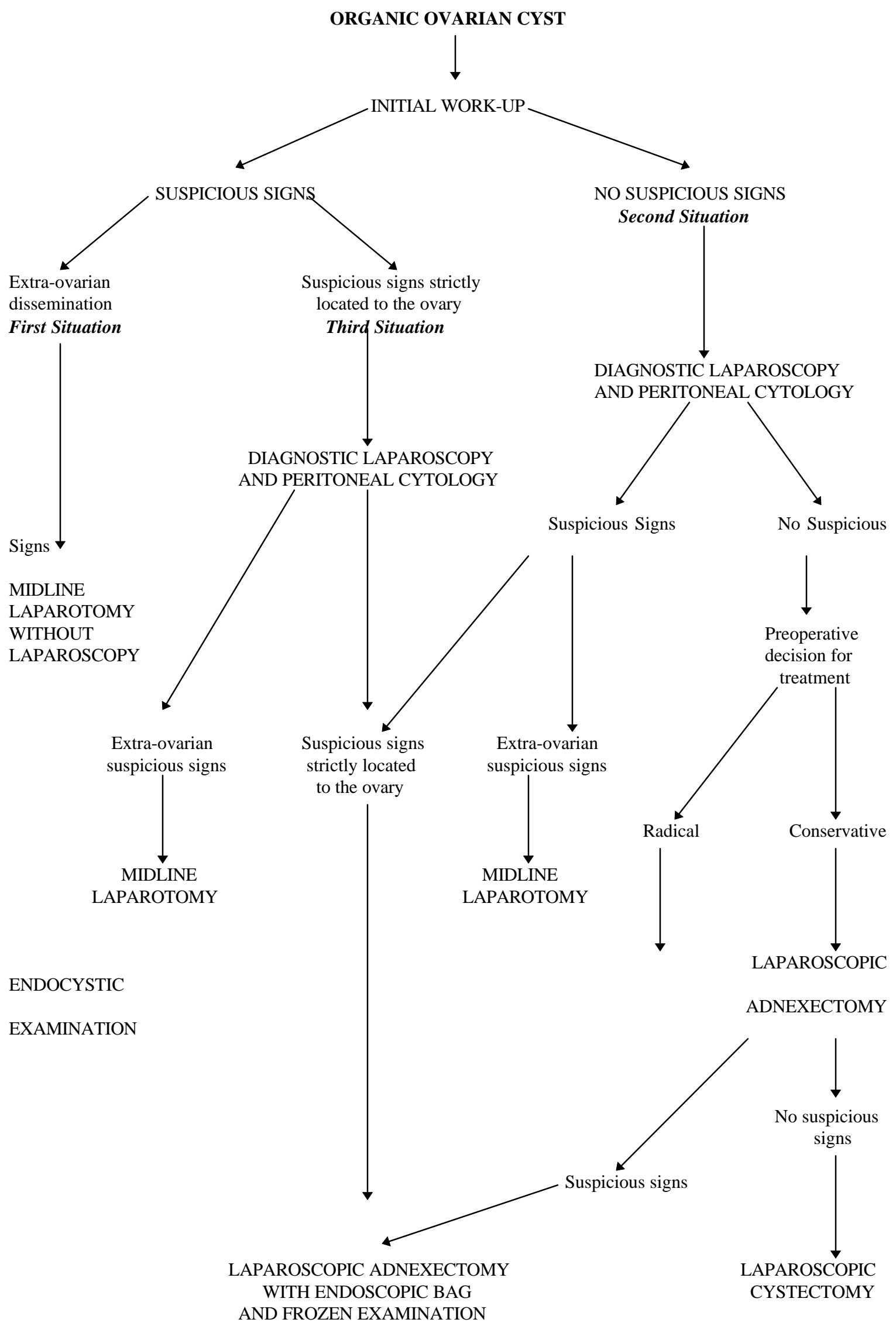

Figure 1. Management of organic ovarian cysts (16) 


\section{REFERENCES}

1. C. Chapron, J.B. Dubuisson, N. Samouh, H. Foulot, F.X. Aubriot, Y. Ansquer \& P. Morice: Treatment of ovarian dermoid cysts. Place and modalities of operative laparoscopy. Surg Endosc 8, 1092-5, (1994)

2. M. Canis, G. Mage, J.L. Pouly, A. Wattiez, H. Manhes \& M.A. Bruhat: Laparoscopic diagnosis of adnexal cystic masses: a 12-year experience with long term follow-up. Obstet Gynecol 83, 707-12, (1994)

3. L. Mettler, G. Caesar, S. Neunzling \& K. Semm K: Stellenwert der endoskopischen ovar-chirurgie, Kritische analyse von 626 pelviskopish operierten ovarialyzsten an der Universitäts- Fraenklinik Kiel 1990-1991. Geburtsh u Frauenheilk 53, 253-7, (1993)

4. F. Nezhat, C. Nezhat, C.E., Welander \& B. Benigno: Four ovarian cancers diagnosed during laparoscopic management of 1011 women with adnexal masses. Am J Obstet Gynecol 167, 790-6, (1992)

5. K. Semm \& L. Mettler: Technical progress in pelvic surgery via operative laparoscopy. Am J Obstet Gynecol 138, 121-7, (1980)

6. H. Reich: Laparoscopic oophorectomy and salpingo-oophorectomy in the treatment of benign tubo-ovarian disease. Int J Fertil 32, 233-6, (1987)

7. C. Nezhat, F. Nezhat \& S.L. Silfen: Videolaseroscopy for oophorectomy. Obstet Gynecol 165, 1323-30, (1991)

8. C.P. Perry \& J.C. Upchurch: Pelviscopic adnexectomy. Am J Obstet Gynecol 162, 79-81, (1990)

9. D.E. Pittaway, P. Takacs \& P. Bauguess P: Laparoscopic adnexectomy: a comparison with laparotomy. Am J Obstet Gynecol 171, 385-95, (1994)

10. H. Tintara \& R. Leetanaporn: Cost-benefit analysis of laparoscopic adnexectomy. Int J Gynecol Obstet 50, 21-5, (1995)

11. J.F. Daniell, B.R. Kurtz \& J.Y.Lee: Laparoscopic oophorectomy: comparative study of ligatures, bipolar coagulation and automatic stapling devices. Obstet Gynecol 80, 325-8, (1992)

12. S.S. Sheth \& A. Malpani: Technique of vaginal oophorectomy during vaginal hysterectomy. J Gynecol Surg 10, 197-203, (1994)
13. C. Chapron, J.B. Dubuisson, X. Fritel, P. Morice, F.X. Aubriot \& H. Foulot: Techniques et indications de l'utilisation du sac endoscopique dans la prise en charge des kystes ovariens. Contracept Fertil Sex 22, 682-4, (1994)

14. C. Chapron, J.B. Dubuisson \& S. Capella-Allouc: Salpingo-oophorectomy for adnexal masses. Place and results for operative laparoscopy. Eur J Obstet Gynecol Reprod Biol, (In press)

15. C. Chapron, S. Capella-Allouc \& J.B. Dubuisson: Treatment of adnexal torsion using operative laparoscopy. Hum Reprod 11, 998-1003, (1996)

16. C. Chapron, J.B. Dubuisson, X. Fritel \& D. Rambaud: Management of organic ovarian cysts: Place and modalities for laparoscopy. Hum Reprod Update, (In press) 